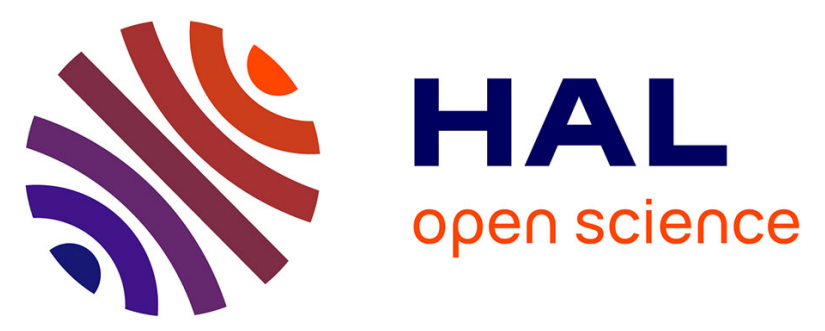

\title{
Proteasome- and SCF-dependent degradation of yeast adenine deaminase upon transition from proliferation to quiescence requires a new F-box protein named Saf1p.
}

Stéphanie Escusa, Jurgi Camblong, Jean-Marc Galan, Benoît Pinson, Bertrand Daignan-Fornier

\section{To cite this version:}

Stéphanie Escusa, Jurgi Camblong, Jean-Marc Galan, Benoît Pinson, Bertrand Daignan-Fornier. Proteasome- and SCF-dependent degradation of yeast adenine deaminase upon transition from proliferation to quiescence requires a new F-box protein named Saf1p.. Molecular Microbiology, 2006, 60(4), pp.1014-25. 10.1111/j.1365-2958.2006.05153.x . hal-00023448

\section{HAL Id: hal-00023448 \\ https://hal.science/hal-00023448}

Submitted on 27 Apr 2007

HAL is a multi-disciplinary open access archive for the deposit and dissemination of scientific research documents, whether they are published or not. The documents may come from teaching and research institutions in France or abroad, or from public or private research centers.
L'archive ouverte pluridisciplinaire HAL, est destinée au dépôt et à la diffusion de documents scientifiques de niveau recherche, publiés ou non, émanant des établissements d'enseignement et de recherche français ou étrangers, des laboratoires publics ou privés. 


\section{Proteasome- and SCF-dependent degradation of yeast adenine}

deaminase upon transition from proliferation to quiescence requires a new F-box protein named Saf1p

Stéphanie Escusa $^{1}$, Jurgi Camblong ${ }^{1,2}$, Jean-Marc Galan ${ }^{3}$, Benoît Pinson ${ }^{1}$ and Bertrand Daignan-Fornie $^{1 *}$

${ }^{1}$ Institut de Biochimie et Génétique Cellulaires, CNRS/Université Bordeaux 2 UMR 5095, 33077 Bordeaux Cedex, France; ${ }^{3}$ Institut Jacques Monod-CNRS/Universités Paris 6 \& 7, 75251 Paris Cedex 05, France.

Running title: Adenine deaminase degradation dur ing quiescence

Key words: Stationary phase, protein degradation, purine metabolism, RAS pathway, Saccharomyces cerevisiae

${ }^{*}$ Corresponding author:

B. Daignan-Fornier

Institut de Biochimie et Génétique Cellulaires

CNRS UMR 5095

1 , rue Camille Saint-Saëns

33077 Bordeaux Cedex

France

Tel : (33) 556999055

Fax : (33) 556999059 
e-mail : B.Daignan-Fornier@ibgc.u-bordeaux2.fr

${ }^{2}$ present address: Department of Cell Biology, University of Geneva, Sciences III, 30 Quai E. Ansermet, 1211, Geneva 4, Switzerland 


\section{Abstract}

In response to nutrient limitation, Saccharomyces cerevisiae cells enter into a nonproliferating state termed quiescence. This transition is associated with profound changes in gene expression patterns. The adenine deaminase encoding gene $A A H I$ is among the most precociously and tightly down-regulated gene upon entry into quiescence. We show that $A A H 1$ down regulation is not specifically due to glucose exhaustion but is a more general response to nutrient limitation. We also found that Aah1p level is tightly correlated to RAS activity indicating thus an important role for the proteine kinase A pathway in this regulation process. We have isolated three deletion mutants, srb10, srb11 and safl (ybr280c) affecting $A A H 1$ expression during post-diauxic growth and in early stationary phase. We show that the Srb10p cyclin-dependent kinase and its cyclin, Srb11p, regulate $A A H 1$ expression at the transcriptional level. By contrast, Saf1p, a previously uncharacterized F-box protein, acts at a post-transcriptional level by promoting degradation of Aahlp. This post-transcriptional regulation is abolished by mutations affecting the proteasome or constant subunits of the SCF (Skp1-Cullin-F-box) complex. We propose that Saf1p targets Aah1p for proteasomedependent degradation upon entry into quiescence. This work provides the first direct evidence for active degradation of proteins in quiescent yeast cells. 


\section{Introduction}

Most eukaryotic cells spend the majority of their natural lives in a non-proliferating state and up to $60 \%$ of the biomass on Earth consists of quiescent micro-organisms (Gray et al., 2004). Understanding the mechanisms involved in the establishment of stationary phase thus appears as a central biological issue. Since cell proliferation results in an increase of the biomass, it is strictly conditioned by nutrient availability. Therefore, proliferation of unicellular microorganisms, such as the yeast Saccharomyces cerevisiae, tightly reflects growth medium richness. When nutrients start to be limiting, yeast cells stop dividing and enter into a quiescent state named stationary phase (Gray et al., 2004). Transition from proliferation to stationary phase takes a few days and is associated with typical modifications, such as accumulation of glycogen and a decrease in cell wall porosity (Werner-Washburne et al., 1993). All these changes make yeast cells more resistant to environmental stresses and therefore increase their survival probability. Indeed, yeast mutants which are unable to properly enter into stationary phase are more sensitive to stress and die precociously under starvation conditions (Werner-Washburne et al., 1993). Two major nutrient limitation signaling pathways, named RAS and TOR, have been characterized. Defects in these pathways either mimic entry into stationary phase even in the presence of nutrients or abolish cells capacity to enter properly into quiescence under nutrient limitations (for review see (Herman, 2002)).

Microarray experiments have given an overview of yeast gene expression variations associated with entry into quiescence (Gasch et al., 2000; Radonjic et al., 2005). Clearly, expression of thousands of genes is affected, with as many genes being up- or down-regulated (DeRisi et al., 1997; Gasch et al., 2000). Similarly, during exit from stationary phase, expression of multiple genes is affected (Martinez et al., 2004; Radonjic et al., 2005). At the 
molecular level, Holstege and coworkers found that during stationary phase, RNA polymerase II (polII) was poised onto specific promoters corresponding to early activated genes upon reentry into proliferation (Radonjic et al., 2005). Interestingly, a link between phosphorylation of RNA polII C-terminal domain (CTD), ability to survive in stationary phase and the RAS pathway has been reported (Howard et al., 2002). Finally, the Srb10p and Srb11p proteins, which are associated to the mediator complex and involved in RNA polII CTD phosphorylation, are critical for expression of specific genes and for survival upon starvation (Chang et al., 2001; Howard et al., 2002). This suggests that active transcriptional regulation is required for proper entry into quiescence. While multiple informations on transcriptional processes involved in stationary phase establishment and exit are arising, very little is known on post-transcriptional events associated with transition from proliferation to quiescence. In fact, protein translation still occurs during stationary phase (Boucherie, 1985; Fuge et al., 1994) and this process is critical for survival (Choder, 1993). However, despite a growing interest on protein degradation, almost nothing is known about this process in the cell "quiescence cycle" (entry, maintenance and exit from quiescence).

$A A H 1$ is an interesting gene model for shedding light on the active molecular mechanisms associated with entry and exit from quiescence. AAHI encodes adenine deaminase which converts adenine to hypoxanthine. Microarray data show that $A A H 1$ is one of the earliest genes expressed when yeast cells exit from stationary phase (Martinez et al., 2004; Radonjic et al., 2005), it is also among the most precociously and tightly downregulated genes when cells shift from proliferation to quiescence (Gasch et al., 2000). In this work, we have isolated three mutants affecting $A A H l$ expression in early stationary phase. Our data show that $A A H 1$ regulation takes place both at transcriptional and posttranscriptional levels. We show that Srb10p and Srb11p are necessary for proper transcriptional regulation of $A A H 1$ while a new F-box protein named Saf1p (Ybr280p) is 
essential for specific degradation of Aah1p upon nutrient starvation through an SCF- and proteasome-dependent mechanism. 


\section{Results}

\section{Adenine deaminase is strongly down regulated in response to nutrient limitation}

Microarray experiments have shown that transcription of the yeast $A A H 1$ gene decreased at the diauxic transition (DeRisi et al., 1997). Consistently, we could not detect adenine deaminase specific activity in protein crude extracts from post-diauxic wild-type yeast cells, while it was estimated at $181 \mathrm{mUnits} / \mathrm{mg}$ of protein in extracts from exponentially growing cells. This effect was clearly correlated to a lower amount of Aah1p (Fig. 1A) and to a decreased of the expression of $A A H 1$ transcript monitored by northern blot (Fig. 1B). The decrease of $A A H 1$ expression was the most pronounced upon diauxic shift which corresponds to glucose exhaustion (Fig. 1B) while none of the other environmental stresses that we have tested had an effect on Aah1p (Fig. 1C). In order to mimic glucose exhaustion, exponentially growing cells were transferred to either water or a glucose deprived medium. Clearly, in both cases such a brutal starvation did not result in a rapid decrease of Aah1p (Fig. 1D). These data strongly suggest that Aah1p regulation is the result of an adaptation process rather than a response to starvation stress.

To elucidate whether Aah1p low expression, when cells enter post-diauxic phase, was due to decreased growth rate (increased doubling time) or to nutrient limitation, we first modulated cells doubling time under conditions where nutrients are not limiting. This was done by growing the cells at different temperatures $\left(22^{\circ} \mathrm{C}\right.$ and $\left.30^{\circ} \mathrm{C}\right)$ or in either poor SD or rich SDcasa media. As expected, yeast cells grown in SDcasa medium at $22^{\circ} \mathrm{C}$ and $30^{\circ} \mathrm{C}$ had very different doubling times (Fig. 2A). We found that the level of Aah1p was slightly lower in cells growing at $22^{\circ} \mathrm{C}$ (about $80 \%$ of the amount found in control cells growing at $30^{\circ} \mathrm{C}$ ) and that in both cultures, the decrease of Aah1p expression corresponded to the bend of the growth curve. Similarly, Aah1p expression was basically the same in cells grown in poor SD 
and rich SDcasa media (Fig. 2A). We conclude that Aah1p expression is principally down regulated in response to nutrient limitation.

The specificity of the nutrient limitation signal was then estimated by monitoring Aah1p steady state levels under conditions where any of the three ingredients of SD medium (glucose, ammonium sulfate or yeast nitrogen base) becomes limiting for growth. In all cases, nutrient limitation led to an early entry into stationary phase and to a decrease in the expression of Aah1p (Fig. 2B). In this experiment, Aah1p expression strongly decreased in cultures still containing significant amount of glucose (Fig. 2B lower right panels), thus establishing that the decrease in $A A H 1$ expression is not a specific response to carbon limitation, but rather a general response to nutrient exhaustion.

\section{Aahlp expression is controled by the RAS cAMP pathway}

RAS and TOR are key pathways regulating stationary phase establishment in response to nutrient limitation. We thus evaluated their role in Aah1p down-regulation. We found that expression of Aah1p was not strongly affected in a tor 1 tor ${ }^{\text {ts }}$ double mutant (Fig. 3A) or in a wild-type strain treated with rapamycin, a TOR specific inhibitor (data not shown). Furthermore, mutations in several genes involved in the TOR pathway (SIT4, RIM15, RTG1, RTG3, MSK1) had no major effect on $A A H 1$ expression (data not shown).

The expression of Aah1p was then assayed in a RAS2val19 dominant mutant. This mutant, because it makes the RAS pathway constitutively active, does not enter stationary phase properly (Howard et al., 2002; Toda et al., 1985). Clearly, in a RAS2val19 mutant the expression of Aah1p remained high in post-diauxic and stationary phases (Fig. 3B). A similar effect, although slightly less pronounced, was found in the BY4742 background using the RAS2val19 allele carried on a plasmid (data not shown) and in the W303 background carrying the double iralira2 knock-out mutations in which the RAS pathway is constitutively activated 


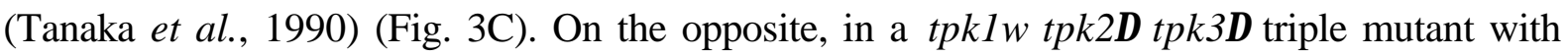
low residual protein kinase A (PKA) activity, Aah1p amount was very low even during exponential growth (Fig. 3D). This effect was partially released by a bcyl mutation, as expected since Bcylp is the PKA regulatory subunit (Fig. 3D). Finally, we found that the RAS pathway effect on Aah1p is independent of Msn2p and Msn4p, two transcription factors involved in the stress response which are PKA downstream targets. Indeed, the msn $2 m s n 4$ double mutant behaved similarly to the wild-type strain in both exponential and stationary phases (Fig. 3E). Furthermore, in the msn2msn4 mutant, Aah1p expression was still deregulated by the RAS2val19 mutation (Fig. 3E).

\section{SRB10, SRB11 and SAF1 (YBR280c) are required for AAH1 regulation}

To get a better understanding of the molecular mechanisms leading to $A A H 1$ regulation, we took advantage of an $A A H 1-l a c Z$ fusion to screen for deregulated mutants within a collection of knock-out mutants. In a wild-type strain expressing this AAHI-lacZ construct, $\beta$-galactosidase activity was strongly regulated by growth phase (Fig. 4A, open circles), as expected if the fusion correctly mimics $A A H 1$ expression. The $A A H 1-l a c Z$ fusion was introduced in 75 pools, each containing 60 to 70 individual yeast knock-out mutants, and expression of the fusion in the transformants was estimated after 3 days by a colorimetric assay. Three mutants allowing higher expression of the fusion were isolated and the mutated genes were identified by sequencing the specific tag introduced during gene knock-out (Winzeler et al., 1999). The three mutants corresponded to knock-out of the SRB10 and $S R B 11$ genes and of the uncharacterized $Y B R 280 c$ open reading frame that we renamed $S A F 1$ ( $\underline{S} C F$ Associated Factor, see below). We verified that expression of the $A A H 1$-lacZ fusion was indeed higher in these mutants during post-diauxic growth (Fig. 4A). This higher $\beta \mathrm{Gal}$ activity was clearly due to a higher amount of the fusion protein as determined by western 
blot (Fig. 4B). To ensure that the deregulation of the AAHl-lacZ fusion observed in the mutant strains indeed reflects the expression of the endogenous $A A H 1$ gene, steady state levels of $A A H I$ transcript was assayed by northern blot in the wild-type and mutant strains. Our results show that the expression of $A A H I$ is deregulated at the transcriptional level in both $\operatorname{srb10}$ and $\operatorname{srb11}$ mutants (Fig. 4C). This was expected, since both genes encode RNA PolII-associated factors which have been shown to affect the expression of several genes according to growth phase (Chang et al., 2001). Importantly, Srb10p is a cyclin-dependent kinase and Srb11p its cognate cyclin. Therefore, isolation of both mutants in the screen was highly consistent with an important role of this complex in the transcriptional regulation of $A A H 1$. To our surprise, in the safl mutant, the $A A H 1$ transcript level decreased just as in the wild-type control strain during post-diauxic growth (Fig. 4C), while the amount of Aah1-BGal estimated by western blot was much higher in the safl mutant during post-diauxic growth (Fig. 4B). We conclude that Srb10p and Srb11p are transcriptional regulators of $A A H 1$ while Saf1p most probably acts at a post-transcriptional level.

\section{SAF1 regulates adenine deaminase abundance at a post-transcriptional level}

To establish more precisely the role of $S A F 1$ in $A A H 1$ expression, we expressed $A A H 1$ under the control of the tet heterologous synthetic promoter which is not affected by growth phase (Fig. 5A). Clearly, the amount of Aah1p expressed from the tet promoter fusion was still regulated by the growth stage at the protein level (Fig. 5B). Furthermore, Aah1p expression driven by the tet promoter was derepressed in the safl mutant as expected if Saf1p acts at a post-transcriptional level (Fig. 5B). Finally, the effects of srb11 and safl mutations on $A A H 1$-lacZ expression were clearly additive (Fig. 5C - similar results were obtained with $\operatorname{srb10}$ (data not shown)), consistently with the fact that these mutations affect respectively the transcriptional and the post-transcriptional regulation of $A A H 1$. 
Interestingly, Aah1p expressed from the tet promoter was more abundant in post diauxic and stationary phases in the RAS2val19 mutant (Fig. 5D). This result is similar to the one obtained with the safl mutant (Fig. 5B), suggesting that somehow RAS2val19 could mimic a saf1 knock-out. Indeed, we observed that in the RAS2val19 mutant, an integrated functional Saf1p-13Myc fusion was very poorly expressed compared to wild-type (Fig. 5E). This result is in good agreement with previous work by others showing that transcriptional expression of $S A F 1(Y B R 280 c)$ was repressed by overexpression of RAS2val19 (Wang et al., 2004). The low expression of Saf1p in the RAS2val19 mutant strain correlated to an increased amount of Aah1p, suggesting that under these conditions Saf1p could be limiting for Aah1p degradation.

\section{Aah1p degradation in stationary phase is Saflp dependent}

We then investigated whether the post-transcriptional regulation of Aah1p in stationary phase results from a lower translation efficiency or from protein degradation. Because the incorporation of $\left[{ }^{35} \mathrm{~S}\right]$ methionine is very low when cells are in stationary phase, classical pulse chase experiments were not conclusive. We therefore used a construct in which Aah1p was fused to GFP, the two proteins being linked by a TEV protease cleavage site. The whole construct was tagged with a myc epitope and was driven by the tet promoter. As expected, the fusion protein amount was lower in stationary phase indicating that the fusion protein regulation mimics that of the endogenous Aah1p (Fig. 6A). When this fusion was coexpressed with the TEV protease placed under the control of a galactose inducible promoter, cleavage of the fusion protein could be detected with anti-myc and anti-GFP antibodies. We found that, while the GFP half of the cleaved fusion was equally abundant in exponential and stationary phase, the myc-Aah1p half was mostly detected in the extract from exponentially growing cells. Since both halves result from the same synthesis event, this 
result demonstrates that the myc-Aah1p half is specifically degraded in stationary phase, while the GFP half of the protein is not. Finally, in the safl mutant, both halves of the fusion protein were equally stable after TEV cleavage (Fig. 6A) clearly establishing that Saflp is required for Aah1p degradation specifically during post-diauxic and stationary phases. Of note, we observed that the cleavage of the full-length protein seemed to be slightly more efficient in the safl mutant than in the wild-type strain. One explanation could be that Saf1p might affect the cleavage process through an interaction with the fusion protein.

Why should Aah1p be actively degraded upon transition from proliferation to quiescence? One possibility could be that during quiescence, Aah1p becomes misfolded and targeted for degradation. This issue was addressed by directly measuring adenine deaminase in a safl mutant unable to degrade Aah1p. Results presented in figure 6B clearly show a good correlation between Aah1p amount determined by western blot and adenine deaminase activity. We then conclude that during post-diauxic growth Saf1p participates to degradation of enzymatically active adenine deaminase.

\section{Degradation of Aahlp is abolished in SCF and proteasome mutants}

Although the function of Saf1p is not known, it is one of the 21 yeast proteins containing an F-box motif (Willems et al., 2004). Such proteins were shown to recruit specific substrates to the SCF (Skp1-Cullin-F-box) complex and consequently target them for degradation by the proteasome (Hershko and Ciechanover, 1992). We therefore asked whether mutants affecting ubiquitin-conjugating enzyme (Cdc34p), SCF (Cdc53p, Skp1p, Hrt1p) or proteasome (Cim5p) subunits would abolish Aah1p degradation during quiescence.

Indeed, in stationary phase, Aah1p was much more abundant in the hrtl mutant (affected in the RING finger SCF-component) than in the wild-type strain (Fig. 7A). Similarly, Aah1p was stabilized in skp1-12 and $c d c 34-2$ mutants during post-diauxic growth 
and somewhat intermediary in the $c d c 53-1$ mutant (Fig. 7B) possibly because this mutant grows poorly and tends to revert rapidly. The amount of Aah1p was clearly not affected in the F-box $c d c 4-1$ mutant (Fig. 7B) neither by mutations in 14 other F-box encoding yeast genes (MET30, GRR1, YDR131c, YDR219c, YDR306c, YJL149w, YJL204c, YLR097c, YLR224w, YLR368w, YML088w, YNL230c, YNL311c, YORO80w) (data not shown). These results show that the regulatory role of Saf1p is Hrt1p-, Skp1p- and Cdc34p-dependent but is independent of the non-constant SCF F-box subunits.

The role of the proteasome in Aah1p regulation was then evaluated using a cim5-1 temperature sensitive mutant affecting the proteasome function. CIM5 (RPTI) encodes an ATPase component of the $26 \mathrm{~S}$ proteasome complex. Our results show that Aah1p was much more abundant in the cim5-1 mutant than in the wild-type in stationary phase (Fig. 7C). Together these results establish that both the SCF and the proteasome are required for proper post-transcriptional regulation of Aah1p. 


\section{Discussion}

We found that yeast adenine deaminase synthesis is regulated both at transcriptional and post-transcriptional levels. This dual regulation could account for the discrepancies between our results (Fig. 1C) and microarray data (Gasch et al., 2000) in response to stresses. Indeed, $A A H 1$ transcript level was strongly affected by various environmental stresses while we found no effect at the protein level. The fact that down regulation of $A A H 1$ in response to nutrient limitation takes several hours indicates that it is the result of a slow adaptative process to nutrient exhaustion rather than an instantaneous response to starvation or stress.

Why should Aah1p be degraded during quiescence? Our data do not support a model in which Aah1p would become misfolded but rather argue for the fact that Aah1p amount should be strictly controlled during establishment of- and/or exit from quiescence. Indeed, $A A H 1$ is one of the most precociously transcribed genes when yeast cells exit from stationary phase (Martinez et al., 2004). However, we found that the lack of Aah1p degradation in a safl mutant does not affect entry or survival in stationary phase (S. E., J. C. and B. D.-F. unpublished data) and the relationship between Aah1p expression and quiescence remains puzzling. At this point, we cannot formally exclude that Aah1p could have an additional cellular function distinct from its adenine deaminase activity although there is no phenotypical evidence for such a role. Alternatively, it could be that guanylic nucleotides synthesis should decrease to allow proper entry into stationary phase, as shown in the bacteria Bacillus subtilis (Ratnayake-Lecamwasam et al., 2001). This possibility is further supported by the fact that all yeast GMP biosynthesis genes are regulated by nutrient availability at the transcriptional level (Escobar-Henriques et al., 2003). However, none of the other purine salvage enzymes tested (Amd1p, Apt1p, Gua1p, Hpt1p, Imd2p) appear to be regulated at the post-transcriptional level (S. E. and B. D.-F. unpublished data). Importantly, although $A A H 1$ 
and IMD2 are both tightly regulated in response to nutrient limitation (Fig. 1B, (EscobarHenriques et al., 2003)) neither srb10, srb11 or saf1 mutations have an effect on IMD2-lacZ expression (J. C. and B. D.-F. unpublished data), indicating that similar regulations occur through different means. However it is noteworthy that Srb10p and Srb11p were found critical for transcriptional down-regulation of the $A C T 1$ gene in stationary phase (Chang et al., 2001). Our results with $A A H 1$ further substantiate the role of Srb10p and Srb11p in transcriptional regulation upon post-diauxic and stationary phases. According to recent results, RNA polymerase II is maintained upstream of many stationary phase repressed genes (Radonjic et al., 2005). It is thus tempting to speculate that Srb10p and Srb11p could contribute to this phenomenon. Although, the metabolic signal that triggers Aah1p degradation is not identified yet, we have shown that the RAS pathway plays an important role in the down-regulation of $A A H 1$. Our data (Fig. 5E) show that a constitutively active RAS pathway results in a low Saf1p steady state level correlated to an increased amount of Aah1p. These data provide a simple and attractive explanation for the high level of Aah1p observed in the RAS2val19 mutant. However, we cannot rule out that part of the effect of the RAS pathway on $A A H 1$ expression could be Saf1p-independent.

The transition from proliferation to quiescence is associated to changes in the proteome composition (Werner-Washburne et al., 1996). This implies that new specific proteins are synthesized while others disappear. Since quiescent cells do not divide and considering the long half-life of peptide bonds (Kahne D, 1988), disappearance of proteins cannot result from passive dilution but is necessarily the result of an active degradation process. This process could be dependent on the ubiquitin proteasome system since a major role for ubiquitin in stationary phase has already been suggested by the fact that ubiquitin is required for survival during starvation (Finley et al., 1987; Swaminathan et al., 1999). In this 
work we have established that Aah1p degradation is Saf1p-, SCF- and proteasome-dependent. Saf1p was shown to interact with Aah1p (Ho et al., 2002), our unpublished data) and to immunoprecipitate with Skp1p and Cdc53p (Seol et al., 2001), two constant subunits of $S$. cerevisiae SCF. Thus, as shown for other F-Box proteins, Saf1p could link its target (Aah1p) to the SCF core subunits. We therefore propose that Saf1p could participate to a new SCF complex specifically targeting Aah1p for proteasome-dependent degradation during the yeast quiescent cycle. 


\section{Materials and methods}

\section{Strains and media}

Yeast strains used in this study are described in Table I. Yeast cells were grown in YPD (1\% yeast extract, $2 \%$ peptone, and $2 \%$ glucose $)$ or in synthetic medium $(0.17 \%$ nitrogen base, $0.5 \%$ ammonium, and $2 \%$ of either glucose (SD), raffinose or galactose). SDcasaWA is SD medium supplemented with $0.2 \%(\mathrm{w} / \mathrm{v})$ casaminoacids (Difco), tryptophan (40 mg/L) and adenine (40 mg/L). Histidine (10 mg/L), lysine (10 mg/L), uracil (20 mg/L), and methionine $(20 \mathrm{mg} / \mathrm{L})$ were added when necessary.

\section{DNA manipulations}

To express the $A A H 1$ gene under control of a repressible tetracycline promoter (tet), AAH1 coding sequence was amplified by PCR using oligonucleotides 531 (5'-CGC GGA TCC ATA ATG GTT TCT GTG GAG TTT-3') and 532 (5'-CCA ATG CAT CTA ATG CGA ATA TTT AGT GAC-3'). This PCR fragment digested with BamHI and NsiI was cloned in pCM189 (Gari et al., 1997) opened with BamHI and PstI. The resulting plasmid was named p2088. AAH1-lacZ fusion (p1459) was constructed by PCR amplification of AAH1 with oligonucleotides 276 (5'-CAG CAT CTC CAG AGC ATG-3') and 277 (5'-ACG CGT CGA CCA TGC GAA TAT TTA GTG ACT AC-3'), followed by digestion with HpaI-SalI and cloned at SmaI-SalI sites in YEp356 (Myers et al., 1986). The tet-mycAAH1-tev-GFP plasmid was constructed as follows. AAHI was PCR amplified using oligonucleotides 276 and 277 (see above), the PCR product was cloned after restriction with HpaI-SalI in SmaI-SalI sites of p1257, containing the GFP-coding sequence. The resulting plasmid was named p1384. A TEV cleavage site between $A A H 1$ and GFP was introduced using two complementary oligonucleotides containing the TEV cleavage site sequence (5'-TCG AGC TTC TGC TTC 
TGA AAA TTT GTA TTT TCA AGG-3' and 5'-TCG ACC TTG AAA ATA CAA ATT TTC AGA AGC AGA AGC-3') ligated at the unique Sall site of p1384. The resulting plasmid was named p2767. An AAH1-tev-GFP fragment obtained by PCR amplification on p2767 with oligonucleotides 531 (see above) and 1118 (5'- CCA ATG CAT TAT TTG TAC AAT TCA TCC ATA CC-3') was digested by BamHI-NsiI and cloned at BamHI-PstI sites of p2717 (a derivative of pCM189 in which a myc tag has been introduced downstream of the tet promoter).

PGal TEV (pYEF1-T TEV-HA) (Sagot et al., 1999) was used to express TEV protease in yeast under control of a galactose inducible $(G A L)$ promoter; pYEF1-T was used as control vector. The URA3 CEN pRAS2val19 is a kind gift from Dr. M Wigler.

Strain expressing a 13myc epitope-tagged version of Saf1p at the SAF1 locus (Y2685) was constructed as follows: a 13myc-His3MX6 cassette was amplified by PCR using pFA6a13myc-His3MX6 (Longtine et al., 1998) as a template with primers containing SAFl-specific sequences: 1176 (5'-ACGGAATCCAAAATGCAAAATCGAAATGACACCTAAAAAT GAA TTC GAG CTC GTT TAA AC-3') and $1177 \quad\left(5^{\prime}-\mathrm{T}\right.$ GGT GGCTGGCAAACCGGTGCATtAATCATCAAG AAG CAT CGG ATC CCC GGG TTA ATT AA-3'). The PCR product was transformed into a wild type strain (BY4741) and transformants were selected on medium lacking histidine. Correct integration of the module by homologous recombination at the $S A F 1$ locus was verified by PCR.

\section{Western blot analyzes}

Strains were grown overnight in appropriate medium and then diluted at $\mathrm{OD}_{600}=0.1$. Typically, cells were harvested at several times during growth: exponential growth (8 hours), post-diauxic stage (24 hours) and early stationary phase (48 hours) (however, we are fully aware that entry in stationary phase is a continuum rather the succession of discrete steps). 
For each growth stage, an equivalent quantity of cells was removed $\left(6.10^{7}\right.$ cells $)$. Collected cells were disrupted with glass beads in $500 \mu \mathrm{L}$ of TCA $5 \%$. Samples were centrifuged $(16,000 \mathrm{~g}$ during $5 \mathrm{~min})$ and proteins were resuspended in $50 \mu \mathrm{L}$ of SDS-PAGE sample buffer (125 mM Tris/HCl pH 6.8, 5\% SDS, 50\% glycerol, 2\% $\beta$-mercaptoethanol). Extracts were boiled for $5 \mathrm{~min}$ and $10 \mu \mathrm{L}$ were loaded onto a $12.5 \%$ SDS-PAGE gel. After electro-transfer, PVDF membranes were incubated with a 1:10,000 dilution of monoclonal mouse anti-myc antibodies (9E10; Covance), or a 1:15,000 dilution of polyclonal rabbit antibodies raised against the N-term part (from amino acyl 1 to 177) of Aah1p, or a 1:30,000 dilution of polyclonal rabbit antibodies raised against Ade13p (full-length), or a 1:25,000 dilution of polyclonal antibodies anti-GFP (Santa Cruz Biotechnology) or 1:10,000 dilution of polyclonal antibodies anti- $\beta$ Galactosidase (Rockland) or 1:25,000 dilution of polyclonal antibodies antiAct1p gracefully given by Dr. JA Cooper (Washington University School of Medicine, St. Louis, MO). Primary antibodies were detected with horseradish peroxidase-conjugated antirabbit or anti-mouse secondary antibodies followed by chemiluminescence.

\section{Screen for deregulated mutants for AAH1 expression}

A collection of 4767 haploids yeast knock-out mutants (purchased from EUROSCARF) was screened for mutants with altered expression of the bifunctional AAH1-lacZ fusion reporter. Using a colometric assay (X-gal), we could discriminate after 2 or 3 days, colonies with high $\beta$-gal activity (deep blue) of those with low activity (light blue). Mutant strains distributed in 75 micro-plates of 60 to 70 individual strains were grown for 2 days on YPD medium. Strains from each plate were pooled and transformed with plasmid p1459 expressing the AAH1-lacZ fusion. Transformants were replicated on two plates of SDcasaWA solid medium. One plate was conserved and the other was tested for $\beta$-gal activity by "agar-overlay" after 3 days at $30^{\circ} \mathrm{C}: 1 \mathrm{~mL}$ of chloroform was added on plate and then $10.2 \mathrm{~mL}$ of a solution containing $5 \mathrm{ml}$ 
agarose 1\%, $5 \mathrm{ml} \mathrm{KPi} \mathrm{1M} \mathrm{pH} \mathrm{7,} 100 \mu \mathrm{L}$ SDS 10\% (w/v) and $100 \mu \mathrm{L}$ 5-bromo-4-chloro-3indolyl- $\beta$-D-galactopyranoside (X-gal) solubilized in $\mathrm{N}$-N-dimethyl formamide. $\beta$-gal activity of colonies was estimated by their capacity to degrade X-gal, leading to a blue color. 35 strains were selected for a deep blue coloration after 3 days. 32 false positive candidates were eliminated. Then, we identified the mutated gene in the 3 remaining mutants by sequencing the deletion cassette KanMX4 which contains a specific sequence tag (Winzeler et al., 1999). These three mutations corresponded to the knock-out of SRB10 and SRB11 genes, and $Y B R 280 c$ an open reading frame of unknown function that we renamed SAF1.

\section{Glucose assay}

Glucose concentration was determined by using the glucose assay kit (ref GAGO-20) (Sigma, Saint Louis, MI) or the "D- glucose/D-fructose" kit (ref. 10139106035, Roche)

\section{Northern blot analyzes}

Yeast strains were grown in the same conditions as for western blot analysis. Total RNAs were isolated using the TRI-Reagent RNA/DNA/Protein isolation reagent kit (EUROMEDEX). RNA blots were prepared as described previously (Denis et al., 1998) and probed with a PCR fragment specific for the $A A H 1$ gene, amplified from S288C genomic DNA template. After autoradiography, the bound probe was removed from the membrane (by treatment with a $0.1 \%$ SDS boiling solution) and then probed again with PDAl gene as a loading control. PDAl was used because its expression was only slightly affected during stationary phase (Wenzel et al., 1995).

\section{$\beta-$ Galactosidase assays}


Cells grown in selective medium for the reporter plasmid (p1459) were collected at several times to assess the expression of AAHI-lacZ during growth. $\beta$-Galactosidase assays were performed as described (Kippert, 1995). $\beta$-Galactosidase units are defined as $\left(A_{420} \mathrm{x}\right.$ $1000) /\left(A_{600} \times \min \times \mathrm{mL}\right)$.

\section{Adenine deaminase assay}

Adenine deaminase activity in protein extracts were measured using a spectrophotometric assay based on a coupled reaction with xanthine oxydase. Hypoxanthine produced from adenine by Aah1p could be followed by a two-step transformation into uric acid by adding commercial xanthine oxydase (Roche). Uric acid appearance was monitored by its specific absorbance at $293 \mathrm{~nm}$. Cells were then washed with water, resuspended in $0.6 \mathrm{~mL}$ breaking buffer (20 mM Tris/HCl pH 7.9, 1 mM EDTA, 5\% glycerol, $1 \mathrm{mM}$ dithiotreitol, and $2 \mathrm{mM}$ phenylmethylsulfonylfluoride) and then broken with glass beads by vortexing 3 times 30 seconds. After centrifugation ( $5 \mathrm{~min}$ at $16,000 \mathrm{~g}$ ), $10 \mu \mathrm{L}$ of the supernatant were used for enzymatic assay. Reaction was carried out in potassium phosphate buffer $100 \mathrm{mM} \mathrm{pH} 7.5$, adenine $6 \mathrm{mM}$, and 0.16 unit of xanthine oxydase. Absorbance was monitored at $293 \mathrm{~nm}$ during $10 \mathrm{~min}$. Protein concentration was determined using the Bio-Rad (Hercules, CA) Protein Micro Assay system with bovine serum albumin as reference standard. 
Acknowledgments: The authors are grateful to I. Sagot for critical reading of the manuscript. We thank Drs. Wigler and Hall for kind gift of yeast strains. This work was supported by grants from ARC (4749) and from CNRS (UMR5095). Stephanie Escusa was supported by a Ligue Contre le Cancer fellowship.

\section{References}

Bai, C., Sen, P., Hofmann, K., Ma, L., Goebl, M., Harper, J.W., and Elledge, S.J. (1996) SKP1 connects cell cycle regulators to the ubiquitin proteolysis machinery through a novel motif, the F-box. Cell 86: 263-274.

Blondel, M., Galan, J.M., and Peter, M. (2000) Isolation and characterization of HRT1 using a genetic screen for mutants unable to degrade Gic $2 p$ in saccharomyces cerevisiae. Genetics 155: 1033-1044.

Boucherie, H. (1985) Protein synthesis during transition and stationary phases under glucose limitation in Saccharomyces cerevisiae. J Bacteriol 161: 385-392.

Brachmann, C.B., Davies, A., Cost, G.J., Caputo, E., Li, J., Hieter, P., and Boeke, J.D. (1998) Designer deletion strains derived from Saccharomyces cerevisiae S288C: a useful set of strains and plasmids for PCR-mediated gene disruption and other applications. Yeast 14: 115-132.

Chang, Y.W., Howard, S.C., Budovskaya, Y.V., Rine, J., and Herman, P.K. (2001) The rye mutants identify a role for Ssn/Srb proteins of the RNA polymerase II holoenzyme during stationary phase entry in Saccharomyces cerevisiae. Genetics 157: 17-26.

Choder, M. (1993) A growth rate-limiting process in the last growth phase of the yeast life cycle involves RPB4, a subunit of RNA polymerase II. J Bacteriol 175: 6358-6363. 
Denis, V., Boucherie, H., Monribot, C., and Daignan-Fornier, B. (1998) Role of the myb-like protein bas1p in Saccharomyces cerevisiae: a proteome analysis. Mol Microbiol 30: 557-566.

DeRisi, J.L., Iyer, V.R., and Brown, P.O. (1997) Exploring the metabolic and genetic control of gene expression on a genomic scale. Science 278: 680-686.

Escobar-Henriques, M., Collart, M.A., and Daignan-Fornier, B. (2003) Transcription initiation of the yeast IMD2 gene is abolished in response to nutrient limitation through a sequence in its coding region. Mol Cell Biol 23: 6279-6290.

Finley, D., Ozkaynak, E., and Varshavsky, A. (1987) The yeast polyubiquitin gene is essential for resistance to high temperatures, starvation, and other stresses. Cell 48: 1035-1046.

Fuge, E.K., Braun, E.L., and Werner-Washburne, M. (1994) Protein synthesis in long-term stationary-phase cultures of Saccharomyces cerevisiae. J Bacteriol 176: 5802-5813.

Gari, E., Piedrafita, L., Aldea, M., and Herrero, E. (1997) A set of vectors with a tetracyclineregulatable promoter system for modulated gene expression in Saccharomyces cerevisiae. Yeast 13: 837-848.

Gasch, A.P., Spellman, P.T., Kao, C.M., Carmel-Harel, O., Eisen, M.B., Storz, G., Botstein, D., and Brown, P.O. (2000) Genomic expression programs in the response of yeast cells to environmental changes. Mol Biol Cell 11: 4241-4257.

Gorner, W., Durchschlag, E., Martinez-Pastor, M.T., Estruch, F., Ammerer, G., Hamilton, B., Ruis, H., and Schuller, C. (1998) Nuclear localization of the C2H2 zinc finger protein Msn2p is regulated by stress and protein kinase A activity. Genes Dev 12: 586-597.

Gray, J.V., Petsko, G.A., Johnston, G.C., Ringe, D., Singer, R.A., and Werner-Washburne, M. (2004) "Sleeping Beauty": Quiescence in Saccharomyces cerevisiae. Microbiol Mol Biol Rev 68: 187-206. 
Helliwell, S.B., Howald, I., Barbet, N., and Hall, M.N. (1998) TOR2 is part of two related signaling pathways coordinating cell growth in Saccharomyces cerevisiae. Genetics 148: 99-112.

Herman, P.K. (2002) Stationary phase in yeast. Curr Opin Microbiol 5: 602-607.

Hershko, A., and Ciechanover, A. (1992) The ubiquitin system for protein degradation. Annu Rev Biochem 61: 761-807.

Ho, Y., Gruhler, A., Heilbut, A., Bader, G.D., Moore, L., Adams, S.L., Millar, A., Taylor, P., Bennett, K., Boutilier, K., Yang, L., Wolting, C., Donaldson, I., Schandorff, S., Shewnarane, J., Vo, M., Taggart, J., Goudreault, M., Muskat, B., Alfarano, C., Dewar, D., Lin, Z., Michalickova, K., Willems, A.R., Sassi, H., Nielsen, P.A., Rasmussen, K.J., Andersen, J.R., Johansen, L.E., Hansen, L.H., Jespersen, H., Podtelejnikov, A., Nielsen, E., Crawford, J., Poulsen, V., Sorensen, B.D., Matthiesen, J., Hendrickson, R.C., Gleeson, F., Pawson, T., Moran, M.F., Durocher, D., Mann, M., Hogue, C.W., Figeys, D., and Tyers, M. (2002) Systematic identification of protein complexes in Saccharomyces cerevisiae by mass spectrometry. Nature 415: 180-183.

Howard, S.C., Budovskaya, Y.V., Chang, Y.W., and Herman, P.K. (2002) The C-terminal domain of the largest subunit of RNA polymerase II is required for stationary phase entry and functionally interacts with the Ras/PKA signaling pathway. J Biol Chem 277: 19488-19497.

Jaquenoud, M., Gulli, M.P., Peter, K., and Peter, M. (1998) The Cdc42p effector Gic2p is targeted for ubiquitin-dependent degradation by the SCFGrr1 complex. Embo J 17: 5360-5373.

Kahne D, S.C. (1988) Hydrolysis of a peptide bond in neutral water. J. Am. Chem. Soc. 110: 7529-7534. 
Kippert, F. (1995) A rapid permeabilization procedure for accurate quantitative determination of beta-galactosidase activity in yeast cells.;. FEMS Microbiol. Lett. 128: 201-206.

Longtine, M.S., McKenzie, A., 3rd, Demarini, D.J., Shah, N.G., Wach, A., Brachat, A., Philippsen, P., and Pringle, J.R. (1998) Additional modules for versatile and economical PCR-based gene deletion and modification in Saccharomyces cerevisiae. Yeast 14: 953-961.

Martinez, M.J., Roy, S., Archuletta, A.B., Wentzell, P.D., Anna-Arriola, S.S., Rodriguez, A.L., Aragon, A.D., Quinones, G.A., Allen, C., and Werner-Washburne, M. (2004) Genomic analysis of stationary-phase and exit in Saccharomyces cerevisiae: gene expression and identification of novel essential genes. Mol Biol Cell 15: 5295-5305.

Myers, A.M., Tzagoloff, A., Kinney, D.M., and Lusty, C.J. (1986) Yeast shuttle and integrative vectors with multiple cloning sites suitable for construction of lacZ fusions. Gene 45: 299-310.

Nikawa, J., Cameron, S., Toda, T., Ferguson, K.M., and Wigler, M. (1987) Rigorous feedback control of cAMP levels in Saccharomyces cerevisiae. Genes Dev 1: 931-937.

Radonjic, M., Andrau, J.C., Lijnzaad, P., Kemmeren, P., Kockelkorn, T.T., van Leenen, D., van Berkum, N.L., and Holstege, F.C. (2005) Genome-Wide Analyses Reveal RNA Polymerase II Located Upstream of Genes Poised for Rapid Response upon S. cerevisiae Stationary Phase Exit. Mol Cell 18: 171-183.

Ratnayake-Lecamwasam, M., Serror, P., Wong, K.W., and Sonenshein, A.L. (2001) Bacillus subtilis CodY represses early-stationary-phase genes by sensing GTP levels. Genes Dev 15: 1093-1103.

Sagot, I., Bonneu, M., Balguerie, A., and Aigle, M. (1999) Imaging fluorescence resonance energy transfer between two green fluorescent proteins in living yeast. FEBS Lett 447: 53-57. 
Schwob, E., Bohm, T., Mendenhall, M.D., and Nasmyth, K. (1994) The B-type cyclin kinase inhibitor p40SIC1 controls the G1 to S transition in S. cerevisiae. Cell 79: 233-244.

Seol, J.H., Shevchenko, A., and Deshaies, R.J. (2001) Skp1 forms multiple protein complexes, including RAVE, a regulator of V-ATPase assembly. Nat Cell Biol 3: 384391.

Swaminathan, S., Amerik, A.Y., and Hochstrasser, M. (1999) The Doa4 deubiquitinating enzyme is required for ubiquitin homeostasis in yeast. Mol Biol Cell 10: 2583-2594.

Tanaka, K., Nakafuku, M., Satoh, T., Marshall, M.S., Gibbs, J.B., Matsumoto, K., Kaziro, Y., and Toh-e, A. (1990) S. cerevisiae genes IRA1 and IRA2 encode proteins that may be functionally equivalent to mammalian ras GTPase activating protein. Cell 60: 803807.

Thomas, B.J., and Rothstein, R. (1989) Elevated recombination rates in transcriptionally active DNA. Cell 56: 619-630.

Toda, T., Uno, I., Ishikawa, T., Powers, S., Kataoka, T., Broek, D., Cameron, S., Broach, J., Matsumoto, K., and Wigler, M. (1985) In yeast, RAS proteins are controlling elements of adenylate cyclase. Cell 40: 27-36.

Wang, Y., Pierce, M., Schneper, L., Guldal, C.G., Zhang, X., Tavazoie, S., and Broach, J.R. (2004) Ras and Gpa2 mediate one branch of a redundant glucose signaling pathway in yeast. PLoS Biol 2: E128.

Wenzel, T.J., Teunissen, A.W., and de Steensma, H.Y. (1995) PDA1 mRNA: a standard for quantitation of mRNA in Saccharomyces cerevisiae superior to ACT1 mRNA. Nucleic Acids Res 23: 883-884.

Werner-Washburne, M., Braun, E., Johnston, G.C., and Singer, R.A. (1993) Stationary phase in the yeast Saccharomyces cerevisiae. Microbiol Rev 57: 383-401. 
Werner-Washburne, M., Braun, E.L., Crawford, M.E., and Peck, V.M. (1996) Stationary phase in Saccharomyces cerevisiae. Mol Microbiol 19: 1159-1166.

Willems, A.R., Schwab, M., and Tyers, M. (2004) A hitchhiker's guide to the cullin ubiquitin ligases: SCF and its kin. Biochim Biophys Acta 1695: 133-170.

Winston, F., Dollard, C., and Ricupero-Hovasse, S.L. (1995) Construction of a set of convenient Saccharomyces cerevisiae strains that are isogenic to S288C. Yeast 11: 5355.

Winzeler, E.A., Shoemaker, D.D., Astromoff, A., Liang, H., Anderson, K., Andre, B., Bangham, R., Benito, R., Boeke, J.D., Bussey, H., Chu, A.M., Connelly, C., Davis, K., Dietrich, F., Dow, S.W., El Bakkoury, M., Foury, F., Friend, S.H., Gentalen, E., Giaever, G., Hegemann, J.H., Jones, T., Laub, M., Liao, H., Davis, R.W., and et al. (1999) Functional characterization of the S. cerevisiae genome by gene deletion and parallel analysis. Science 285: 901-906. 
Fig. 1. The level of Aah1p decreases in early stationary phase but not in response to environmental stresses.

A. Growth curve of wild-type yeast strain BY4742 grown in SDcasaWA medium (OD 600: optical density at $600 \mathrm{~nm}$ ). Aliquots were removed at indicated times (dotted lines) and proteins extracts were analyzed by western blot with polyclonal antibodies against Aah1p and Ade13p (as a loading control).

B. Aliquots of wild type BY4742 strain (open circles) were harvested at indicated times (dotted lines). Total RNAs were extracted and expression of $A A H 1$ and PDAI (as a loading control) was analyzed by Northern blot. At each time point, glucose concentration in the medium was determined (closed squares).

C. Wild-type yeast strain BY4242 was grown in YPDA rich medium to mid-log phase. Cells were shifted at time 0 in the same medium supplemented or not (control) with hydrogen peroxide $(0.4 \mathrm{mM})$, ethanol $(7.5 \%), \mathrm{NaCl}(0.3 \mathrm{M})$, or sorbitol $(0.4 \mathrm{M})$. For the "heat shock" conditions, cells were grown in YPDA rich medium at $25^{\circ} \mathrm{C}$ to mid-log phase and shifted at $37^{\circ} \mathrm{C}$ (time 0 ). Samples were collected at indicated times and were analyzed by western blot with polyclonal antibodies against Aah1p.

D. Wild type strain was grown in SDcasaWAU medium to mid log phase and was shifted at time 0 in water $\left(\mathrm{H}_{2} \mathrm{O}\right)$ or in the same medium deprived of glucose. Samples were collected at indicated times and analyzed as in $\mathrm{C}$.

Fig. 2. Aah1p is down regulated in response to nutrient limitation.

A. Growth curves of a prototrophic wild-type strain FY4 grown in SDcasa at $30^{\circ} \mathrm{C}$ (crosses), or in SDcasa at $22^{\circ} \mathrm{C}$ (circles) or in $\mathrm{SD}$ at $30^{\circ} \mathrm{C}$ (diamonds) are represented. The doubling time of the strain under these conditions is respectively 100, 125 and $162 \mathrm{~min}$. Samples were collected at 3 time points corresponding to the intersection between each growth curve and 
the dotted lines (1: exponential growth, E; 2: post-diauxic phase, PD; and 3: stationary phase, S) and proteins extracts were analyzed by western blot with polyclonal antibodies against Aah1p and Ade13p.

B. Wild-type strain FY4 was grown in regular SD medium (diamonds) or in the same medium containing a limiting amount of one of the three SD components (squares: $0.2 \%$ glucose, triangles: $0.05 \%$ ammonium sulphate (AS), crosses: 0.1x Yeast Nitrogen Base). Aliquots were collected and analyzed as in A. Glucose concentration was assayed for the 3 time points. nd stands for not detectable.

Fig. 3. The RAS cAMP pathway controls Aah1p expression.

A. Wild-type (JK9-3da) and tor1 $\Delta$ tor2-21 (SH221) double mutant strains were grown at $30^{\circ} \mathrm{C}$ in SDcasaWAU medium and samples were collected during exponential (E), post-diauxic (PD) and stationary (S) phases. Cells were then shifted at $37^{\circ} \mathrm{C}$ during 1 hour. Proteins were extracted and analyzed by western blot with anti-Aah1p and anti- Ade13p antibodies.

B. Wild-type (SP1) strain and RAS2val19 (SP1Ras2val19) dominant mutant were grown in SDcasaWAU medium. Cells were harvested during exponential (E), post-diauxic (PD) and stationary (S) phases and were analyzed by western blot with antibodies against Aah1p and Ade13p.

C. The double iralira2 double mutant and wild-type strain (W303-1A) were analyzed as in B.

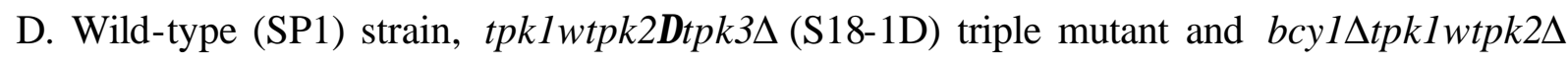
tpk3s(CY800) quadruple mutant were grown in SDcasaWAU at $30^{\circ} \mathrm{C}$ and cells were collected during exponential (E) and stationary (S) phases. Proteins extracts were analyzed as in B. 


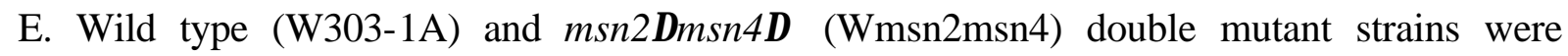
transformed with plasmid expressing RAS2val19 allele or with the empty vector as control. Cells were grown in SDcasaWA medium and were treated as in B.

Fig. 4. Isolation of mutants deregulated for Aah1p- $\beta$ Galactosidase expression.

A. Growth curves of the wild type, $\operatorname{srb} 10 \Delta, \operatorname{srb11\Delta }$, and $\operatorname{safl\Delta }$ yeast strains transformed with AAH1-lacZ plasmid (upper panel) and respective $ß$-galactosidase (ßGal) activity measurements (lower panel).

B and C. Samples of each culture were harvested at 2 time points (1: exponential phase and 2: post-diauxic phase as annotated in growth curve (see A)). For each samples, proteins or total RNAs were extracted. Protein extracts were analyzed by Western blot with polyclonal antibodies against $\beta$-galactosidase and Ade13p (B) and total RNAs extracts were analyzed by Northern blot with an $A A H 1$ specific probe (C); rRNA 18S and 28S were used as loading controls.

Fig. 5. Saf1p acts at a post-transcriptional level.

A. Total RNAs of wild-type strain BY4742 transformed with plasmid expressing $A A H 1$ under the control of a tetracycline repressible promoter (tet-AAH1) were analyzed at exponential (E), post-diauxic (PD) and stationary (S) phases by northern blot with specific probes for $A A H 1$ and PDAl (as a loading control).

B. Wild-type and safl $1 \Delta$ strains carrying the tet-AAH1 plasmid were collected at exponential (E), post-diauxic (PD) and stationary (S) phases and protein extracts were analyzed by western blot with polyclonal antibodies against Aah1p and Ade13p. 


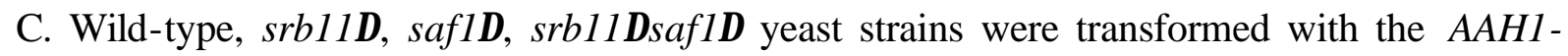
lac $Z$ plasmid. Aliquots were taken at various time points and assayed for $\beta$-galactosidase activity.

D. Wild-type strain (Y2446) was co-transformed with tet-AAH1 and either an empty vector (control) or RAS2val19 plasmid. Cells were collected at exponential (E), post-diauxic (PD).

E. A strain expressing a 13 myc epitope-tagged version of Saf1p at the SAF1 locus (Y2685) and transformed with plasmid expressing RAS2val19 allele (or with the empty vector as control) were grown in SDcasaWA medium. Samples were collected and analyzed as in B with anti-myc epitope, anti-Aah1p, and anti-Act1p antibodies (as loading control)

Fig. 6. Aah1p is degraded through a Saf1p dependent mechanism.

A. Wild type (Y2445) and $\Delta$ safl (Y2447) yeast strains were co-transformed with two plasmids. The first plasmid allows the expression of Aah1p (tagged on $\mathrm{N}$-term extremity with a myc epitope) fused to GFP on C-term (p2774), the two proteins being separated by a TEV endoproteolytic cleavage site (see schematic representation on the left). The second expresses or not (empty control plasmid, pGal) the TEV protease under control of a galactose inducible promoter (pGal TEV). Strains were grown in $2 \%$ galactose synthetic medium and harvested during exponential (E), post diauxic (PD) and stationary (S) phases. Protein extracts were analyzed by western blot with polyclonal antibodies against GFP and Ade13p (as loading control) and monoclonal antibodies against the myc epitope.

B. Total protein extracts of wild type BY4741 and $\Delta$ safl strains were assayed for adenine deaminase activity; in exponential phase (deep grey) and in stationary phase (light grey). Protein from the same extracts were also analyzed by western blot and Aah1p amount was quantified (lower panel); $100 \%$ refers to the amount of Aah1p in the wild type strain in exponential phase. nd stands for not detectable. 
Fig. 7. Aah1p degradation requires proteasome and SCF core subunits.

A. Wild-type and hrtl-m27 yeast strains were transformed with a plasmid expressing $A A H 1$ under the control of the tet promoter and grown at $25^{\circ} \mathrm{C}$. Aliquots were removed during exponential (E) and stationary (S) phases and proteins extracts were analyzed by western blot with antibodies against Aah1p and Ade13p.

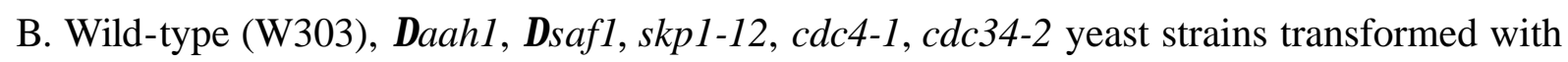
the tet-AAH1 plasmid were grown at $25^{\circ} \mathrm{C}$ during 2 days and were shifted to $37^{\circ} \mathrm{C}$ during 1 hour. Extracts were then analyzed as in A.

C. Wild type and isogenic cim5-1 mutant strains were transformed with a plasmid expressing AAH1 under the tet promoter. Cells were grown in SDcasaWA medium at permissive temperature $\left(25^{\circ} \mathrm{C}\right)$, to exponential $(\mathrm{E})$ and stationary $(\mathrm{S})$ phases. Cells were then shifted at restrictive temperature $37^{\circ} \mathrm{C}$ ) for 1 hour before protein extraction. Protein extracts were immunoblotted with antibodies against Aah1p and Ade13p. 


\begin{tabular}{|c|c|c|}
\hline Name & Genotype & Source \\
\hline BY4741 & MATa, his $3 \Delta 1$, leu $2 \Delta 0$, met $15 \Delta 0$, ura $3 \Delta 0$ & (Brachmann et al., 1998) \\
\hline BY4742 & MAT $\alpha$, his3 $\Delta l$, leu $2 \Delta 0$, lys $2 \Delta 0$, ura $3 \Delta 0$ & (Brachmann et al., 1998) \\
\hline FY4 & MATa, GAL2 & (Winston et al., 1995) \\
\hline SP1 & MATа, leu2, ura3, trpl, his3, ade8, canl & (Toda et al., 1985) \\
\hline TK16-R2V & MATa, leu2, ura3, trp1, his3, ade8, canl, RAS2vall9 & (Toda et al., 1985) \\
\hline Y12786 & 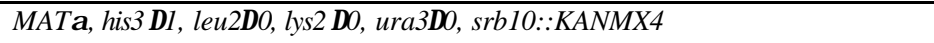 & EUROSCARF \\
\hline Y15351 & 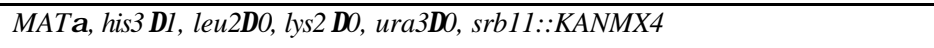 & EUROSCARF \\
\hline $\begin{array}{l}\text { Y17172 } \\
\end{array}$ & 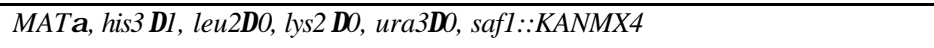 & EUROSCARF \\
\hline Y12935 & 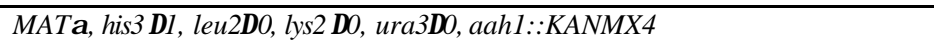 & EUROSCARF \\
\hline Y1664 & 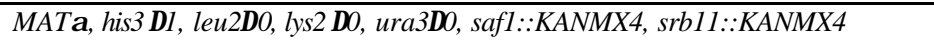 & this study \\
\hline Y2445 & 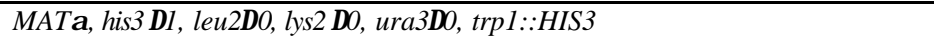 & this study \\
\hline Y2447 & 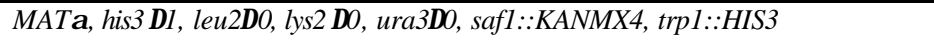 & this study \\
\hline Y2685 & MATo, his3 $\Delta$ I; leu $2 \Delta 0$; lys $2 \Delta 0$; ura3 $\Delta 0$, SAFI-13myc-HIS3MX6 & This study \\
\hline SH221 & $\begin{array}{l}\text { MATa, leu2-3,112 ura3 rme1 trp1 his3 ade } 2 \Delta \text { torl }:: H I S 3-3 \\
\text { tor2::ADE2-3 / YCplac111::tor2-21ts }\end{array}$ & (Helliwell et al., 1998) \\
\hline JK9-3da & MATa leu2-3, 112 trpl ura3 rmel his4 & (Helliwell et al., 1998) \\
\hline SP1 & MATa ade8 his3 leu 2 ura3 trpl canl & M Wigler \\
\hline SP1Ras2val19 & MATa ade8 his3 leu2 ura3 trpl canl RAS2vall9 & M Wigler \\
\hline iralira2 & MATa ade2 can1 his3 leu2 trp1 ura3 iral::LEU2 ira2::URA3 & (Tanaka et al., 1990) \\
\hline Wmsn2msn4 & MATa ade2 canl his3 leu2 trpl ura3 msn4::TRP1 msn2::HIS3 & (Gorner et al., 1998) \\
\hline S18-1D & MATa ade8 ura3 his3 leu2 trp1 tpklw1 tpk2::HIS3 tpk3::TRPI & (Nikawa et al., 1987) \\
\hline CY800 & MATa ade8 canl his3 leu2 trp1 ura3 tpk1w tpk2::HIS3 tpk3::TRP1 bcyl::LEU2 & (Nikawa et al., 1987) \\
\hline $\mathrm{m} 27-15 \mathrm{~b}$ & $\begin{array}{l}\text { hrt1-m27, gic2::LEU2, his3-11::GAL-Gic2-HIS3, ade2-1, trp1-1, can1-100, leu2- } \\
3,112, \text { his3-11,15, ura3, gal-, psi+, ssd1-d2 }\end{array}$ & (Blondel et al., 2000) \\
\hline MJ212 & ts, cdc53-1, ade2-1, trp1-1, can1-100, leu2-3,112, his3-11,15, ura3, GAL+ & (Jaquenoud et al., 1998) \\
\hline ES197 & ts, cdc4-1, ade2-11, trp1-1, can1-100, leu2-3,112, his3-11, 15, ura3, GAL+, psi & (Schwob et al., 1994) \\
\hline ES460 & ts, cdc34-2, ade2-1, trp1-1, can1-100, leu2-3,112, his3-11,15, ura3, GAL+ & (Schwob et al., 1994) \\
\hline Y554 & ts, skpl-12, ade2-1, trpl-1, can1-100, leu2-3,112, his3-11,15, ura3, GAL+ & (Bai et al., 1996) \\
\hline W303 & ade2-1, trp1-1, can1-100, leu2-3,112, his3-11,15, ura3, GAL+, psi+, ssd1-d2 & (Thomas and Rothstein, 1989) \\
\hline
\end{tabular}



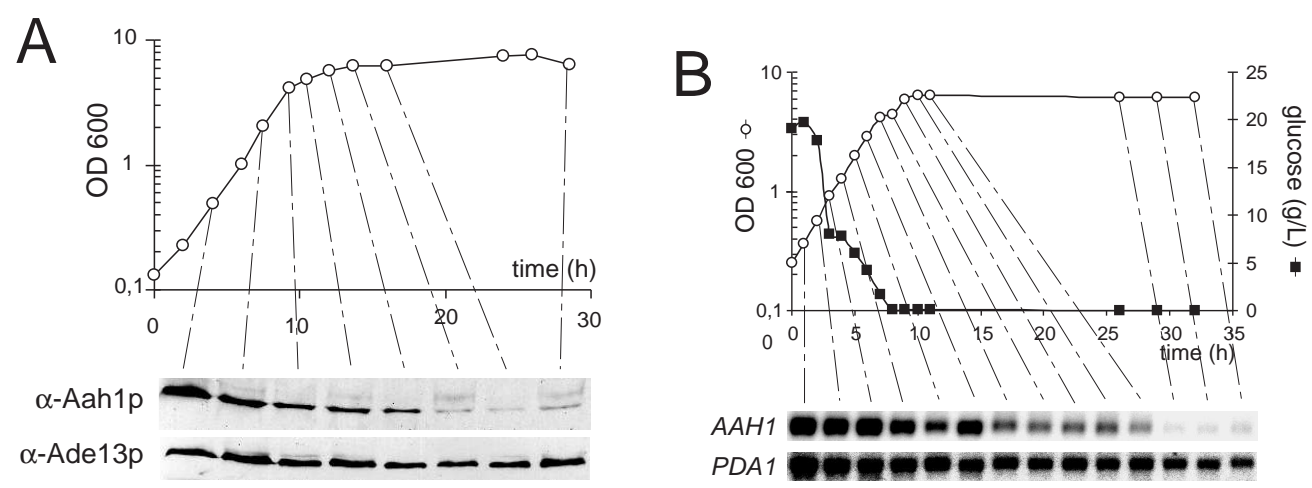

C

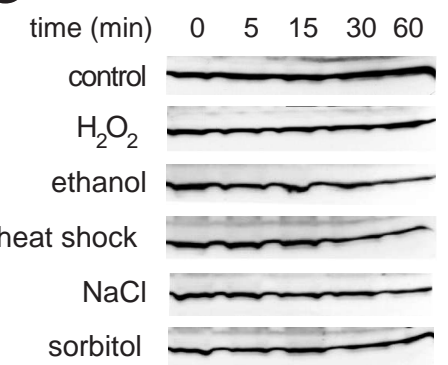

D

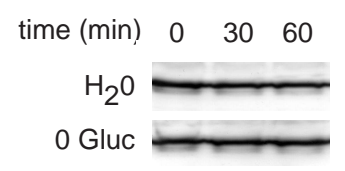

Escusa et al. Fig.1 

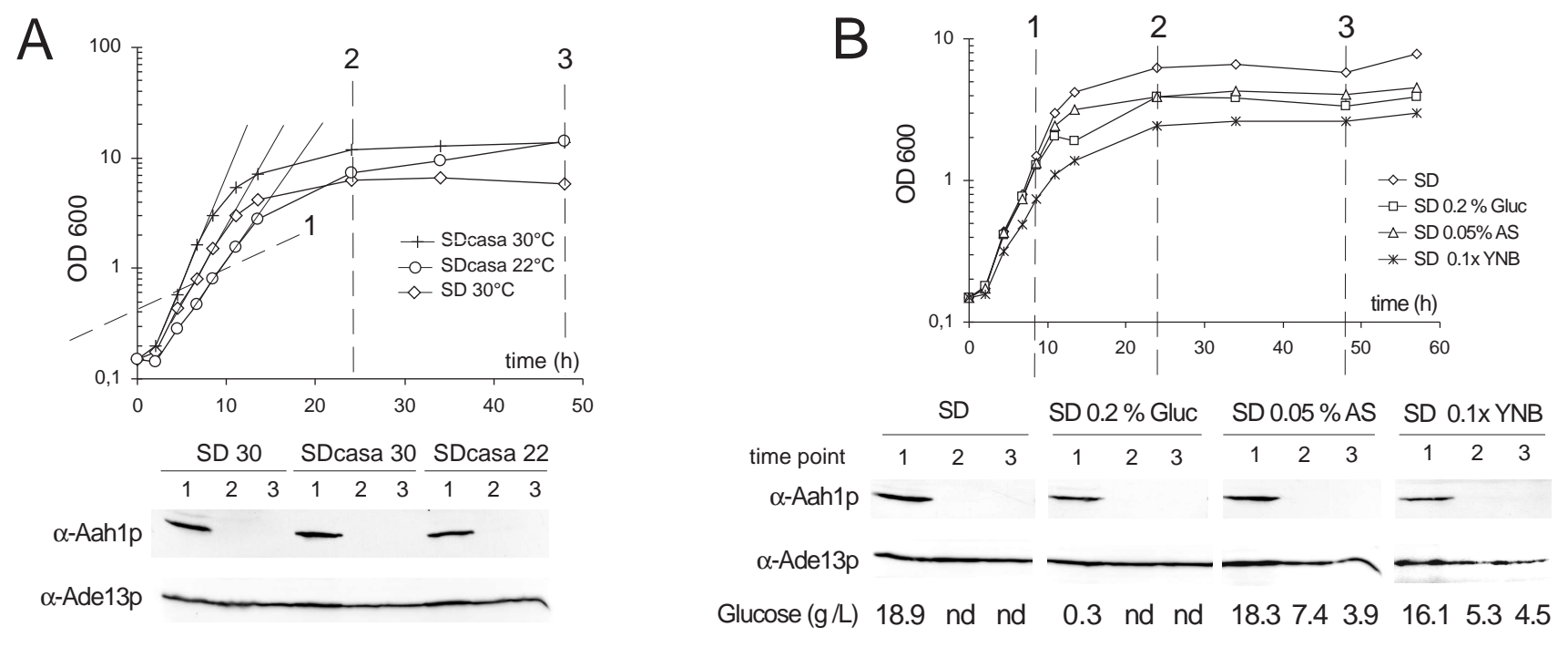

Escusa etal. Fig.2 

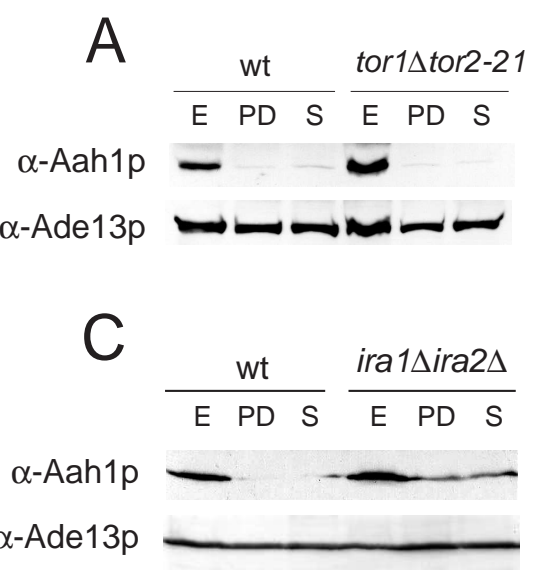
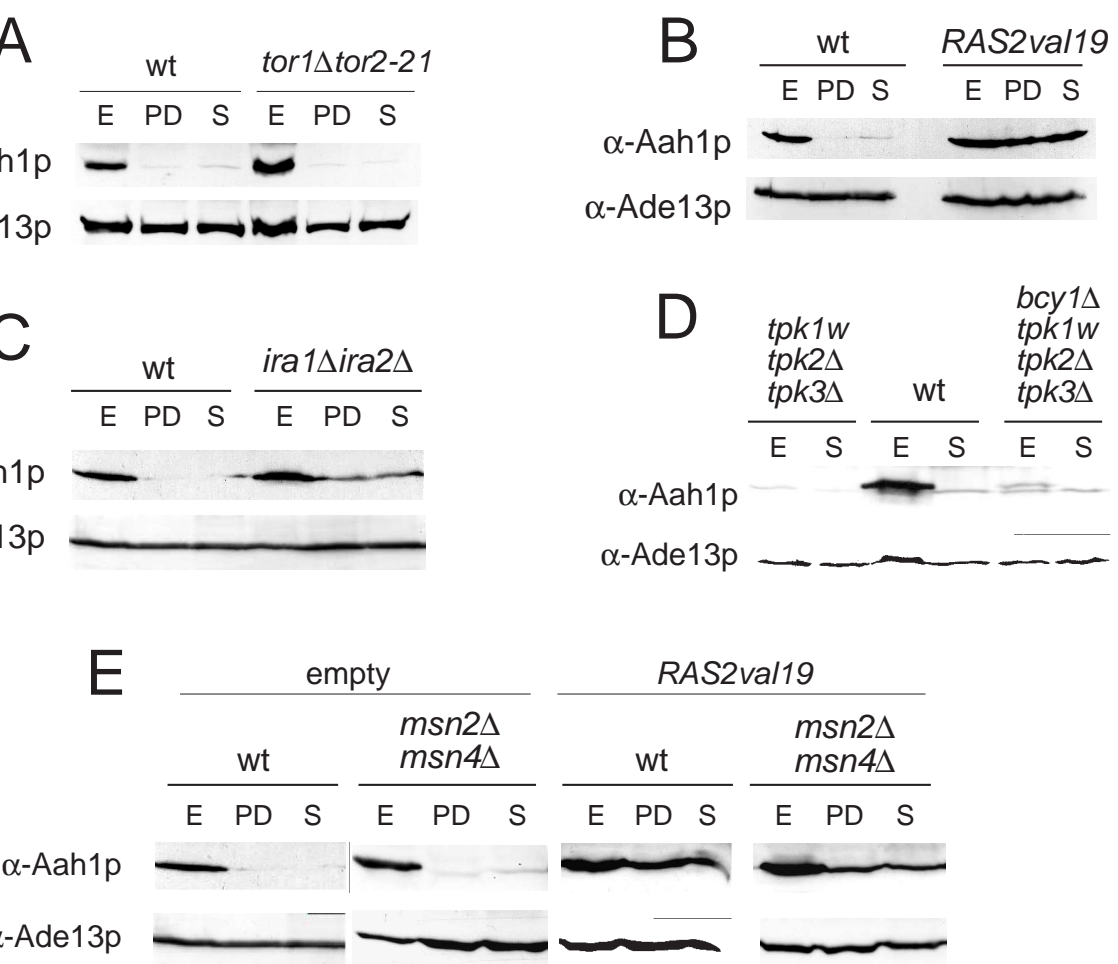

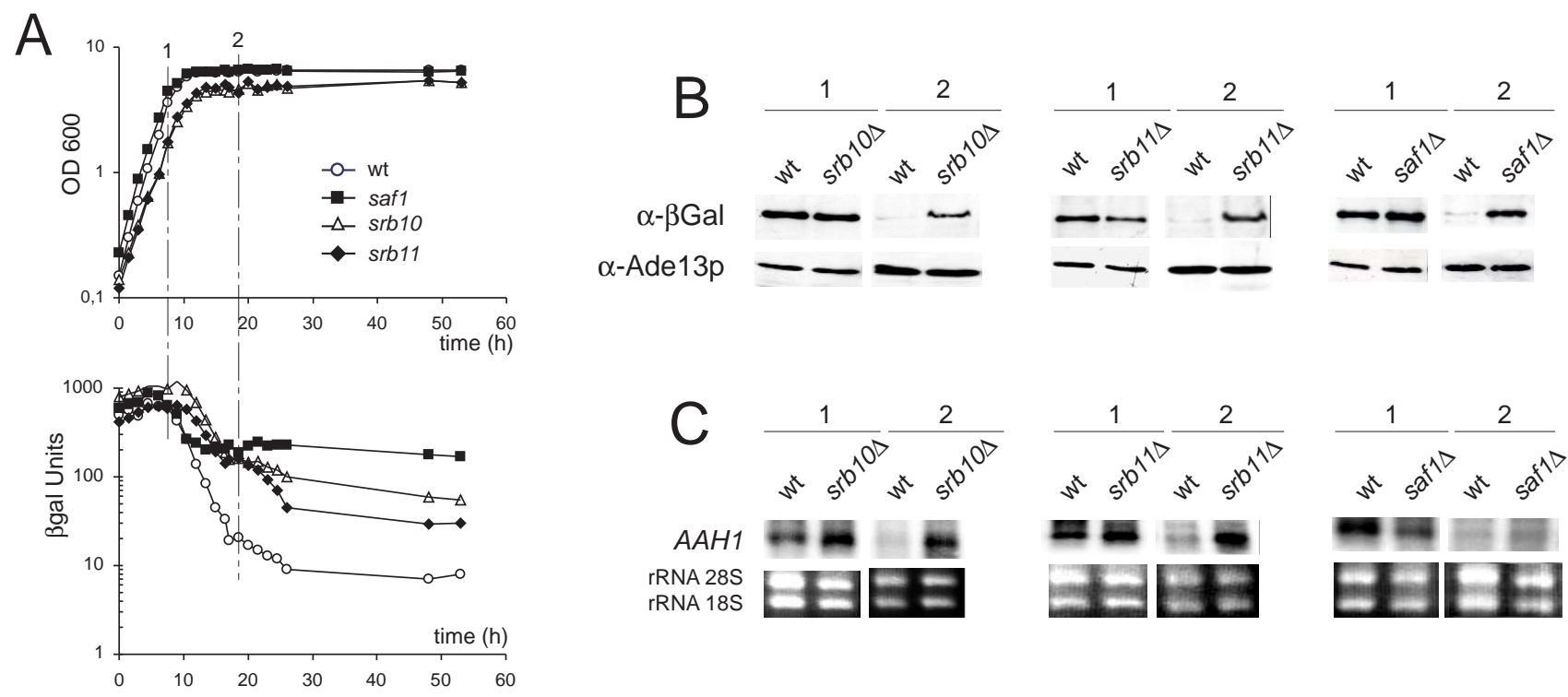

Escusa et al. Fig.4 


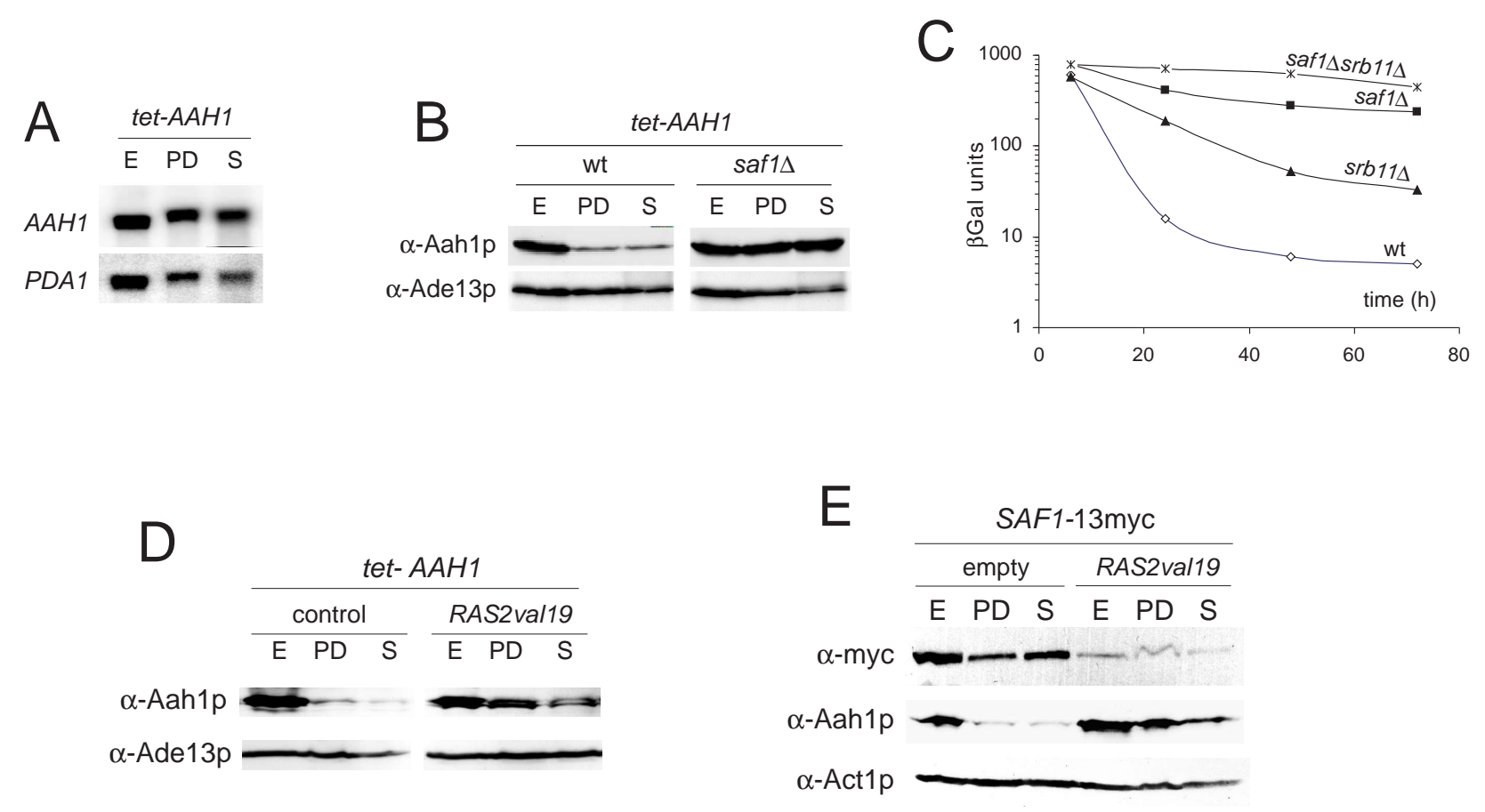

Escusa et al. Fig.5 
A

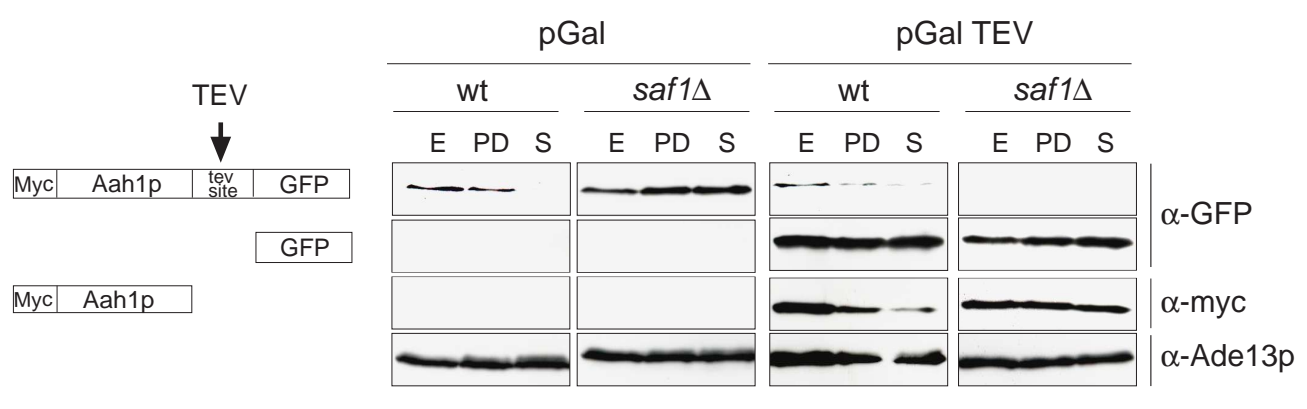

B

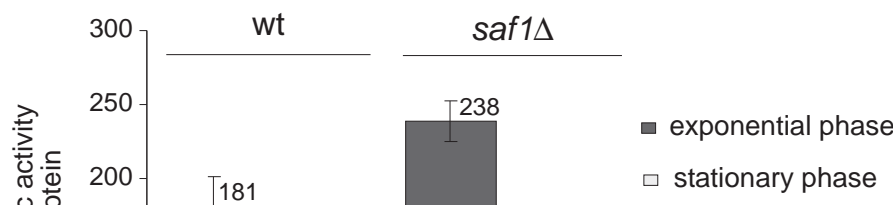

$\begin{array}{rrrrr}\begin{array}{r}\text { Adenine deaminase } \\ \text { activity (\%) }\end{array} & 100 & \text { nd } & 131 & 43 \\ \begin{array}{r}\text { western quantifica- } \\ \text { tion of Aah1p (\%) }\end{array} & 100 & \text { nd } & 125 & 46\end{array}$




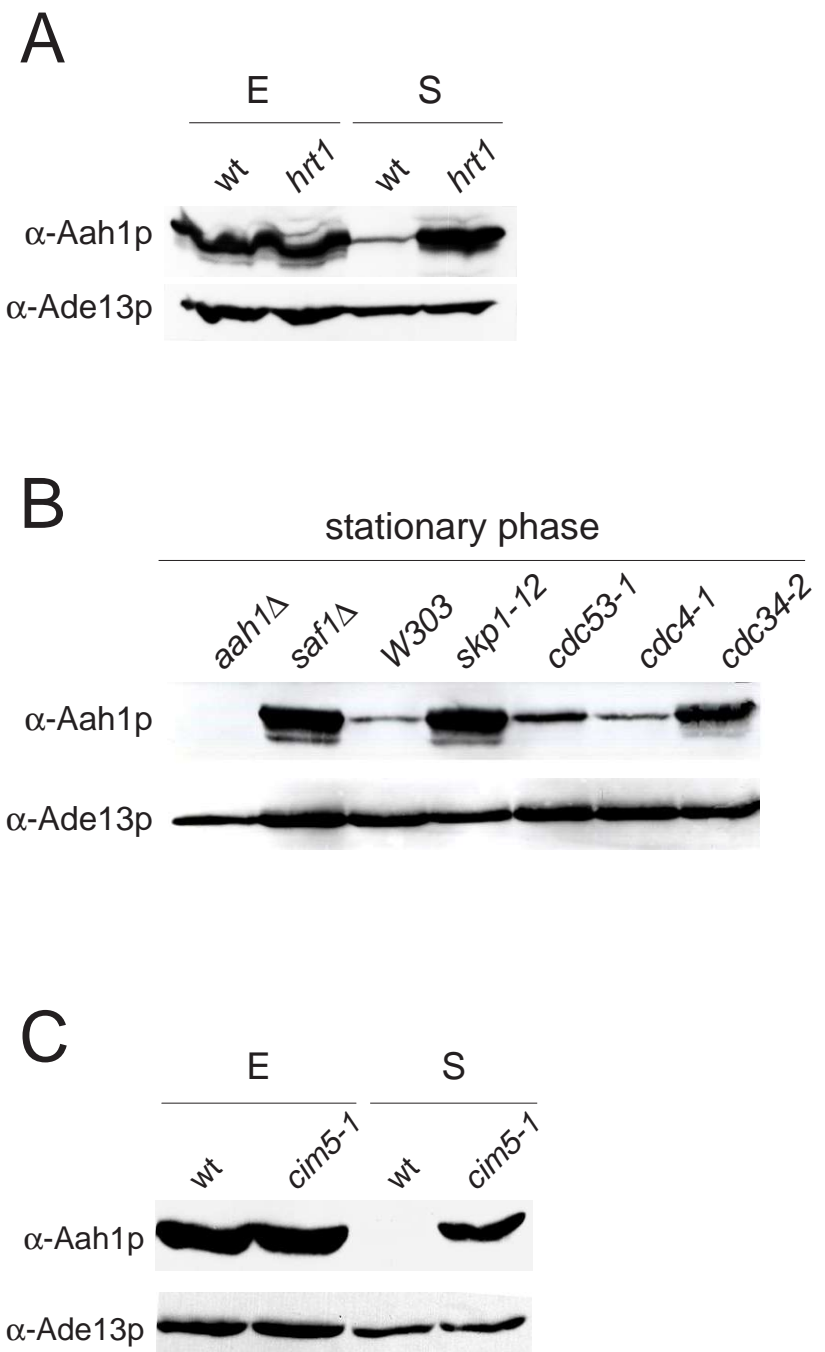

Escusa et al. Fig.7 